\title{
ABOUT SOME SOURCES FOR STUDYING OF RUSSIAN MUSICAL ART REFORMING PROCESS IN $17^{\text {TH }}$ CENTURY
}

\author{
N. P. Parfentiev, parfentevnp@susu.ru, \\ South Ural State University, Chelyabinsk, Russian Federation
}

As a result of the activities of the masters-theorists, collected in Moscow under the orders of Tsar Alexei Mikhailovich in 1652 and 1669, the main musical and hymnographic material of chant handwritten books was revised and musical neumatic (znamenny) notation was improved. In the course of musical reform, in order to more accurately indicate the pitch, masters introduced unified cinnabar red ink signs in the form of letters of the alphabet and marks, written in black ink. The last ones were written in the form of strokes as constitutive parts of znamenny chant neuma. Both of these systems had the function of indicating musical pitch correlations between the neuma of znamenny notation. This is evidence that the musical theoreticians gradually passed from the neuma-formula thinking to the understanding that the melody consists of separate musical "degrees" (steps or sounds). All this brought together the Old Russian and European musical theories and allowed in the future to make a fairly rapid transition to the stylistically new Europeanized art in Russia. The author examines some of the written sources that give the opportunity for a more thorough study of the practical activities of the masters in preparing and conducting reform, the study of the theoretical principles of their editorial work.

Keywords: Old Russian znamenny church singing art, musical reform in Russia in the 17th century, Russian hand-written chant books, "partesniy"(part-singing) polyphonic choral style of church singing.

In the 1650-1670-ies, by the decrees of Tsar Alexei Mikhailovich Romanov, a reform of church chanting art was carried out. For this purpose, Commissions were organized, which included outstanding musical theoreticians (didascaly). As a result of their activity, the main musical and hymnographical material of chant handwritten books was revised and musical neumatic (znamenny) notation was improved [14; 15]. Masters introduced unified cinnabar red ink signs in the form of "zaremba" (letters of the alphabet) and "priznaki" marks, written in black ink. The last ones were written in the form of strokes as constitutive parts of znamenny chant neuma. Both of these systems had the function of indicating musical pitch correlations between the neumes of znamenny notation. This is evidence that the theoreticians gradually passed from the neuma-formula thinking to the understanding that the melody consists of separate musical "degrees" (steps or sounds). All this brought together the Old Russian and European musical theories and allowed in the future to make a fairly rapid transition to the stylistically new Europeanized art in Russia. But how did this transition take place, what time period did it take?

The first step of znamenny chanting musicians to the perception of the ideas about the melody structure consisting of individual sounds should be the appearance of so-named "razvodnoy" variants of chants in the context of the "Bolshoi raspev" (the Great Chant) setting. This style of chanting had extremely prolonged melodies. These chants had in their recordings a large number of melodic "secret-locked", encrypted formulae. They were recorded by a combination of just a few neumes - inscriptions. The music content of these formulas sometimes was very prolonged. Originally it was transmitted in the oral tradition, but then the masters began to reveal it in writing in the form of lengthy "razvody" - explanation of ciphered neumatic formulae by numerous more understandable or simple neumatic signs. This was done to facilitate the singing, including for inexperienced chanters, pupils. Ones of these first "razvodnoy" Great Chant style variants are already found in chant manuscripts of the mid-1580s [for example: 8, p. 127 etc].

The next step in creating the prerequisites for the transitional period was the introduction of special signs into the recording of chants. Such "masters' marks", for example, were used by tsar's singing choristers (diaki) who were trained by master Fedor Krestianin at the turn of the $16^{\text {th }}-17^{\text {th }}$ centuries [7]. At that time, there were indicative letters of the alphabet, that remained and later, as indicating the nuances of singing of the melody: exactly, quickly, quietly, etc. But they paved the way to emerging of the new systems that had the function of indicating sound pitch correlations between the neumes of notations. The Novgorodian Ivan Shaidur achieved particular success in the development of such cinnabar signs [1, p. 494]. They were introduced to universal using in the middle of the $17^{\text {th }}$ century. All this created a basis for the development of the process in the future, that we call transitional one.

At the present stage, with the identification of new sources, handwritten chanting books, it has become possible to expand the range of problems related to the correction of singing manuscripts in the context of the transition period, as well as to more thoroughly examine the practical work of the musical theoreticians in preparing and implementing the reform of church-chant art.

So, in the Yaroslavl Archive there is the preserved Collection of chants which consists of notebooks copied from known at that time "raspevshiks" (composers") manuscripts (the scribe calls them "perevody") $[2 ; 4$, p. 88-89]. Studying of the Collection allows us to identify the causes and features of their editorial work principles at the transition period initial stage.

Note, that in the musical-theoretical treatise of the second half of the $17^{\text {th }}$ century "Tale of zarembas" the 
names of the church-chant masters are listed. They worked over the improvement of the neumatic notation, in particular over the signs as cinnabar letters in the first half of the $17^{\text {th }}$ century in time period "after Lithuanian devastation... under the state of the Tsar and the Grand Duke Mikhail Fedorovich". The pop Luka is called the first of them. It is indicated that he was "Moskvitin, from Wonderworker Nikolay Yavlenskiy (church), located because of Arbat gates" [3, fol. 376 back side - 378]. The study of archival documents of the $17^{\text {th }}$ century shows that Luka Ivanov really served in the church of Nikolay Yavlenskiy "behind the Arbat gate", "in Streletskaya sloboda" (settlement). In the late 20 s and throughout the 30 s, he was the "diakon" (deacon) of this church. During the 40s Luka Ivanov was listed as a priest of the same church. All the years Luka received a "ruga" — a salary from the sovereign's treasury [6]. The church was a stone bilding erected by order of Boris Godunov in 1593. It is obvious that the clergymen of the sovereign's church should have had high professional qualities, primarily in the field of worship service, church singing. The mention of Luka Ivanov as the first one in the group of "Russian philosophers" of Tsar Mikhail Fedorovich's time, who were engaged in the improvement of the ancient musical notation, testifies to his recognition as a master in this sphere.

The creative activity of Luka Ivanov brought him recognition and fame already when he served as diakon of the Moscow Church of Nikolay Yavlenskiy. A striking confirmation of this we found in the mentioned Yaroslavl Collection of chants, which we date to 1630 years. The manuscript contains a number of singing books and large cycles of chants: Hirmologion, Obihod, Oktoechos, Sticheraria of Lent, Theotokion and Crucitheotokion chants from Menaia, Daytime Theotokion and Crucitheotokion chants.

The manuscript has record of 1657 stating that "black" diakon Lavrentiy of Yaroslavl the Tolgskiy monastery, who had previously served in the church of St. Nicholay the Wonderworker in the Moscow "Rublenniy" (Wooden) town, put this book of the singing, named Sticheraria, into the Yaroslavl Cathedral of the Assumption "in remembrance of his and his parents souls" [2, fol. 2 - 463]. Analysis of the documents showed that we are talking about the Moscow Nikolay Yavlenskiy Church near the Arbat Gate. In addition, it was established that when Luka Ivanov became a priest of this church, Leontiy, who soon took the monastic tonsure and the new name of Lavrentiy, took his place as diakon [6].

The fact that the black diakon Lavrentiy was well acquainted with Luka Ivanov is also indicated in the postscript made to sections of the Collection by the hand of Lavrentiy himself (at that time, in the 1630s, Leontiy). So, after Hirmologion, he noted: "The Hirmoses of the Moscow diakon of Nikolay Yavlenskiy (church) Luka Ivanovich Tveritin. From his perevod (musicalhimnographical text, written by a master himself) were copied off" $[2$, fol. 62 back side]. In front of Sticheraria of Lent, he wrote: "Diakon of St. Nicholay Yavlenskiy, Moskvitin Luca Ivanovich Tveritin's Triodi of the Resurrection. From his perevod were written off" [fol. 291]. To other sections, Leontiy also pointed out - after Obihod: "The Obihod of hegumen Pamva, from his

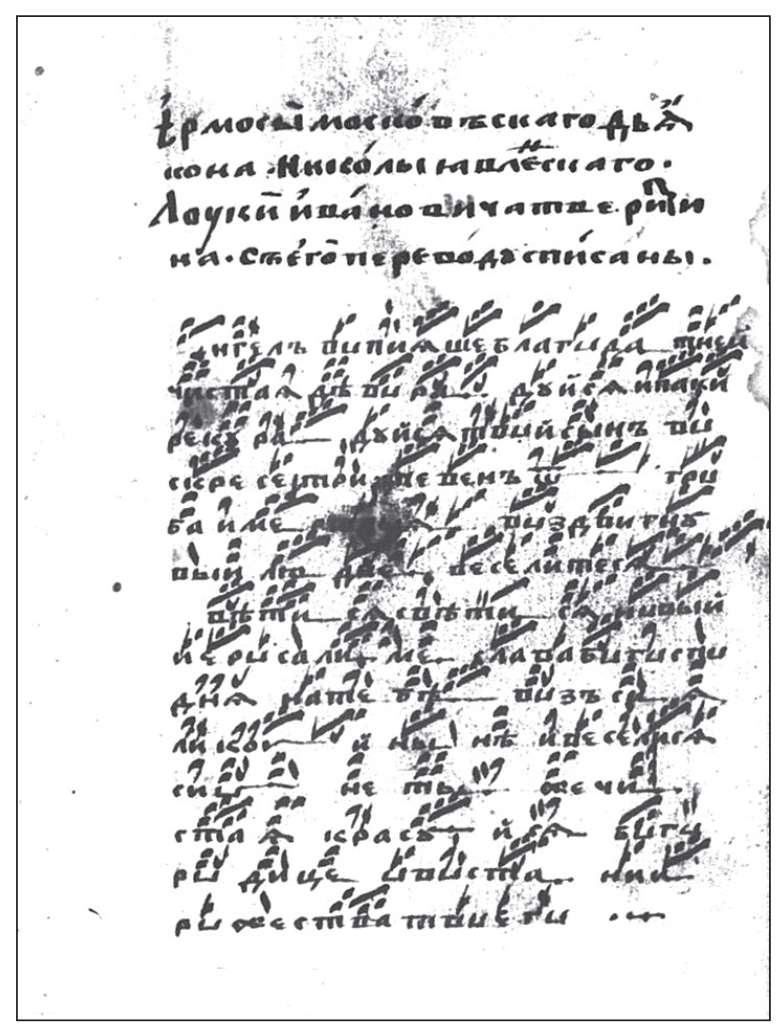

"The Hirmoses of the Moscow diakon of Nikolay Yavlenskiy (church) Luka Ivanovich Tveritin. From his perevod were copied off " [2, fol. 62 back side $]$

perevod was written off" [fol. 192 back side], in front of Oktoechos: "Oktoih of Usolskiy (Stroganovs' masters) perevod" [fol. 193]. All this testifies that the manuscript was compiled from specially selected samples, or lists, chanting books, which became sections of the Collection. Perhaps the customer was Leontiy himself, who carefully watched the writing of the manuscript and accompanied it with the specified remarks.

These records show that Leontiy-Lavrentiy had an extraordinarily respectful attitude towards the "Moscow diakon" Luka. He calls him with "vich", Luka Ivanovich". It in the $17^{\text {th }}$ century was used only in relation to high society persons (members of the tsar's family, boyars and other high court officials, princes), but was also allowed probably between educated people of the same social status. Leontiy considered it obligatory to point out the high authority of the perevods from which the collection was compiled. Consequently, in this context, diakon Luka Ivanovich Tveritin is represented here as an authoritative master. The manuscripts of "his perevod" (written by him) were appreciated; he was already a well-known expert in church singing. We also note that Leontiy pointed out the full name of diakon Luka, calling us his last nickname (Tveritin), which he or his ancestor could receive in Moscow after moving from Tver.

Since the text of the Collection, written in the 1630 s, does not contain any signs or letters as a part of neumatic notation. It confirms the information of "Tale of zarembas" that Luka Ivanovich Tveritin worked on the improvement of musical notation as a priest ("pop Luka"), that is, in the 1640s. Therefore, the manuscript, unfortunately, does not give us an concept of the musical and theoretical search of the master. 


\section{Искусствоведение}

But, undoubtedly, this Collection deserves close attention. There are examples of Luka Tveritin's variants of chants (singsongs) ${ }^{1}$ in other chant manuscripts. The Collection has not chants or their fragments attributed to the authorship of this master. However, the singers themselves did not give indicating of their authorship to chants: pupils and scribes usually accompanied the works of masters with such remarks. Careful study of the chants presented in the lists from Luka's perevod will probably allow us to open his new works.

It is important to note that master Luka Ivanovich Tveritin lived in that period in the history of Russian musical culture, when transformations in the theory of ancient Russian music were ripe. Being in the the best condition of his creative powers, he took part in the search for ways to improve the ancient musical notation. He entered the story as the "creator" of one of the musical "signs" system. He was also the author of chants's singsongs or razvod interpretation of chants' fragments and, finally, was an authoritative copyist of singing books. His manuscripts reflect the early stage of the transition period.

But the activities of the aforementioned state Commissions which included masters-reformers was played the decisive role in the development of the transition period. It is known that the first attempt of the Commission work (1652 - 1654) actually became a preparatory one and did not produce a tangible result. Information on the activities of this Commission is extremely scarce. Only the second Commission (1669-1670), assembled by the tsar's decree, carried out the tasks facing the chant masters. This Commission was actually headed by the outstanding church musician, monk Alexander Mezenets (in the world - Stremoukhov), who also wrote its generalizing theoretical work "Izveshcheniye o soglasneyshikh pometakh..." ("Notification about signs indicating the sound pitch"). The Commission unified and introduced of Ivan Shaidur's signs system [1].

Today it has become possible to study the principles of editorial work, the nature and theoretical approaches of the Second Commission' members, whose activities can be associated with the moving to the final stage of the transition process to a new art.

Recently, we discovered wery intresting manuscript - Collection of chants. One of its handwritings is attributed by us to Faddey Nikitich Subotin the famous Usolsky (Stroganovs') singer and member of the Second Commission $[10]^{2}$. This manuscript is a draft, working version of the masters. There is the editorial correction in it, which was conducted during their work in the commission. The study of the manuscript will reveal the principles and techniques of musical material editing

\footnotetext{
${ }^{1}$ In the theoretical music section of the manuscript of the 17 th century "Extract... of lines" we find a melodic version of a line of chant with the indication "Luka's singing" [3, fol. 424]. Another manuscript contains Luka's interpretation of the "upper" line of the chant from Octoechos [12]. Finally, one of the musical variants of the slavnik "Bowed his Head" in the style of the Great Chant from the service in honor of the Holiday Epiphany of the Lord has the remarque "Luka's singing" [11, fol. 97 back side - 98 back side $]$.

2 The presence of F. Subotin's handwriting has been established by us by comparison with his autographic manuscript. [9]. Read more about the master: [5].
}

also in the context of the sign system implementing. It was based on the masters' awareness that the melody consists of separate sounds, which characterizes the state of art on the eve of the transition to a new musical system.

If Alexander Mezenets explains the theory of the sign system using the examples of the corrected material of Hirmologion, then Faddey Subotin does it on the Holidays Sticheraria.

In the manuscript, we see various methods of editorial work: the demonstration of interpretations with explanation of ciphered neumatic formulae by simple neumes, often with variations of famous masters and schools (see appendix, Fig. 1-3); inserts of melodic materials as corrected versions in the margins [10, fol. 427]; bringing fully revised texts (for example, in the handwriting of another scribe [fol. 363-365]). Of particular note it is the bringing of reference-methodical material to help singers, exercises on mastering the steps of the melodic scale (Fig. 4). This allows us to directly characterize the manuscript as a monument of the final stage of transition. On the manuscript sheets the master noted the steps of his editorial work [fol. 220 back side, 250 back side, 347 back side etc.]: "I has done so far" (Fig. 5, 6). Further detailed study of the manuscript is needed. The research of all these techniques of the masters' editorial work and the obtained results will allow to carry out a reliable decryption of the Old Russian neumatic musical notation, based on theoretical guidelines of reformers.

Recall, that the masters of the Second Commission fulfilled the tasks of correcting chant books and preparing them for publication. But the reform was not fully completed (for example, the printing of the revised chant books was not carried out). The old Russian znamenny singing gave way to a new European musical art with its five-line notation. Thus, the manuscripts reviewed by us clearly characterize the initial and final stages of the transition period to a new art.

A vivid example of the composers' activities after the Second Commission is Pavel Chernitsyn's art work. $\mathrm{He}$, using its results, was able to quickly master the new musical art at the final stage of the transition period. In 1677 Alexander Mezenets prezented him the znamenniy singing book "Menaia" because of Pavel Chernitsyn was the great enthusiast of old Russian chanting. During time when he was the Mezents's pupil, Pavel wrote the interpretations by cinnabar with explanation of ciphered neumatic formulae by simple neumes and corrected the himnographic verbal texts of chants on the margins of some sheets of the book. There was a poetic introduction in the hand-written book. In this part the author of the verse, the eminent musician Alexander Mezenets, told us about his lessons with Chernitsyn:

\section{...How much mastery I have got myself, \\ So much I gave him, the Holy God is witness. \\ I believe that did not hide any secret from him: \\ I handed him all the mysteries of singing...}

$$
[1, \text { p. 419-420, 436] }
$$

Pavel Chernitsyn was descended from Moscow nobles. He was the enthusiast of znaminniy singing, but 
seemed to have no professional attitude to it. From the beginning of the 1670 s and during the period of training with Mezents, he served as a clerk of the "Yamskoy prikaz" (Postal Office) with fixed land and cash salaries. In 1681, he sold the book, Mezenets presented him in 1677, to P. G. Serkov, the clerk of the Moscow Ivanov monastery. [1, p. 436]. It probably lost value to him.

Indeed, in the early of the 1680s Pavel Chernitsyn became famous even at the tsar's court as a composer of new type. He created music in a new European style, the so-called "partesniy" (part-singing). It was the polyphonic choral style of singing. So, for the wedding ceremony of Tsar Fedor Alekseevich (February 15,1682 ), he wrote a polyphonic concert (fivevoices). For this event, the famous court poet Sylvestr Medvedev compiled "Greetings Marriage». Sylvestr on Chernitsyn's order also composed a special poem with congratulations to the newlyweds on behalf of the composer, signed by: "The Yours worst slave and serf Pashka Chernitsyn". [13]. The knowledge gained from Mezenets in the field of reformed Old Russian church singing art allowed Chernitsyn extremely quickly not only to master the new art, but in less than five years to successfully engage in music composing in the new partesniy style.

This fact convincingly indicates that the ancient Russian church singing and the new partesniy art at the final stage of the transition period were not separated by an insurmountable wall, they coexisted in a single time, were parts of the arsenal of artistic expressiveness of the same master. The general movement of Russian musical thought was carried out. It began in the first half of the $17^{\text {th }}$ century as the searching for ways to improve the znamenny neumatic notation and himnographic verbal texts and finished by the end of the century with transition to a new style, new musical theory and notation.

\section{References}

1. Alexander Mezenetz i prochii. Izveschenie... zhelayuschim uchit'sya peniyu (1670) [Alexander Mezenets and others. Notification... to those who wish to learn singing (1670)]. Publ. N.P. Parfentiev, Z.M. Guseynova. Chelyabinsk, 1996, $584 \mathrm{p}$

2. GAYaO. Kol. Rukop. Inv. 1. № 459 (97).

3. GIM. Sin. Pev., № 219.

4. Opisaniye kollektsii rukopisey Gosudarstvennogo arkhiva Yaroslavskoy oblasti XIV-XX vv. [Description of the collection of manuscripts of the State Archives of the Yaroslavl Region of the $14^{\text {th }}-20^{\text {th }}$ centuries]. Sost. V. V. Luk'yanov. - Yaroslavl', 1957, pp. 88-89.

5. Parfentiev N.P., Parfentieva N.V. Russkiy raspevshchik i muzykal'nyy teoretik XVII v. Faddey Nikitin Subotin i yego novootkrytyye proizvedeniya [Russian scribe and music theorist of the 17th century Faddey Nikitin Subotin and his newly discovered works]. Pamyatniki kultury. Novye otkrytiya. Ezhegodnik, 1987 [Monuments of culture. New discoveries. Yearbook, 1987]. Moscow, 1988, pp. 138-149.

6. Parfentiev N.P. Tvorcheskaya deyatel'nost' moskovskogo mastera tserkovno-pevcheskogo iskusstva XVII v. Luki Ivanovicha Tveritina [The creative activity of Luka Ivanovich Tveritin, the Moscow master of church singing art of the $17^{\text {th }}$ century]. Vestnik Uzhno-Ural'skogo gosudarstvennogo universiteta. Seriya: Sotsial'no-gumanitarnye nauki [Bulletin of the South Ural State Universiti. Series: Social Sciences and the Humanities], 2009, v.12, pp. 57—62.

7. Parfentiev N.P., Parfentieva N.V. Khronika tvorcheskoy deyatel'nosti Fedora Krest'yanina v 1598-1607 gg. [Chronicle of creative activity Feodor Krestjanin's in 1598-1607 years]. Kultura i iskusstvo $v$ pamyatnikakh i issledovaniyakh: Sb. nauch. tr. [Culture and art in monuments and research: Collection of proceedings]. Chelyabinsk, 2006, v. 4, pp. $100-129$.

8. Parfentieva N.V. Tvorchestvo masterov drevnerusskogo pevcheskogo iskusstva XVI-XVII vv. [The creative works of the Old Russian chanting art of the $16^{\text {th }}-17^{\text {th }}$ centuries]. Chelyabinsk, 1997, $338 \mathrm{p}$.

9. RGB. F. 199. № 146.

10. RGB. F. 210. № 12 .

11. RNB. Kir.-Bel. № 638/895.

12. RNB. Titov. № 4455.

13. Sazonova L.I. Pridvornyye poety $17^{\text {th }} \mathrm{v}$.: stikhitvornomuzykal'yyee kompozitsii [Court poets of the $17^{\text {th }}$ century: poetic and musical compositions]. Russkoye muzykal'noye barokko: tendentsii i perspektivy issledovaniya. Materialy mezhdunar. nauch. konf. [Russian musical baroque: trends and prospects of research. Materials of the international scientific conference]. Moscow, 2016, pp. 340-347.

14. Parfentiev N.P. Preparing and conducting of musical reform in Russia of 1650-1670-ies. Vestnik Uzhno-Ural'skogo gosudarstvennogo universiteta. Seriya: Sotsial'no-gumanitarnye nauki [Bulletin of the South Ural State Universiti. Series: Social Sciences and the Humanities], 2017, v. 17, № 3, pp. 79-87.

15. Parfentiev N.P. The condition of Old Russian musical art by the middle of the $17^{\text {th }}$ century and the prerequisites for its reforming. Journal of Siberian Federal University. Humanities \& Social Sciences, 2017, v. 10, № 7, pp.1025-1031.

Received Desember 4, 2018 
Appendix

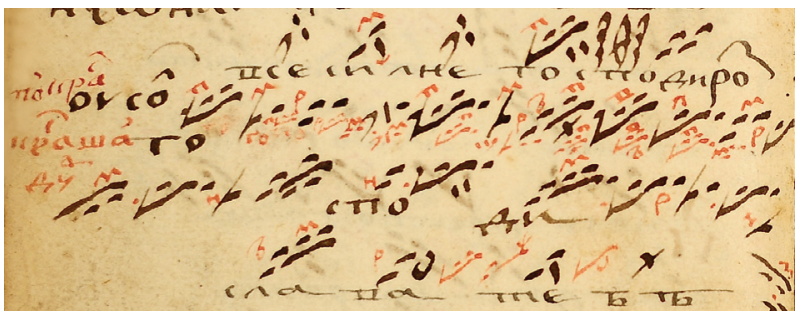

Fig. 1. "Fita" formula in razvods in Usolsky (black ink) and Ivan Shaidur's (cinnabar) variants $[10$, fol. 30 back side ]

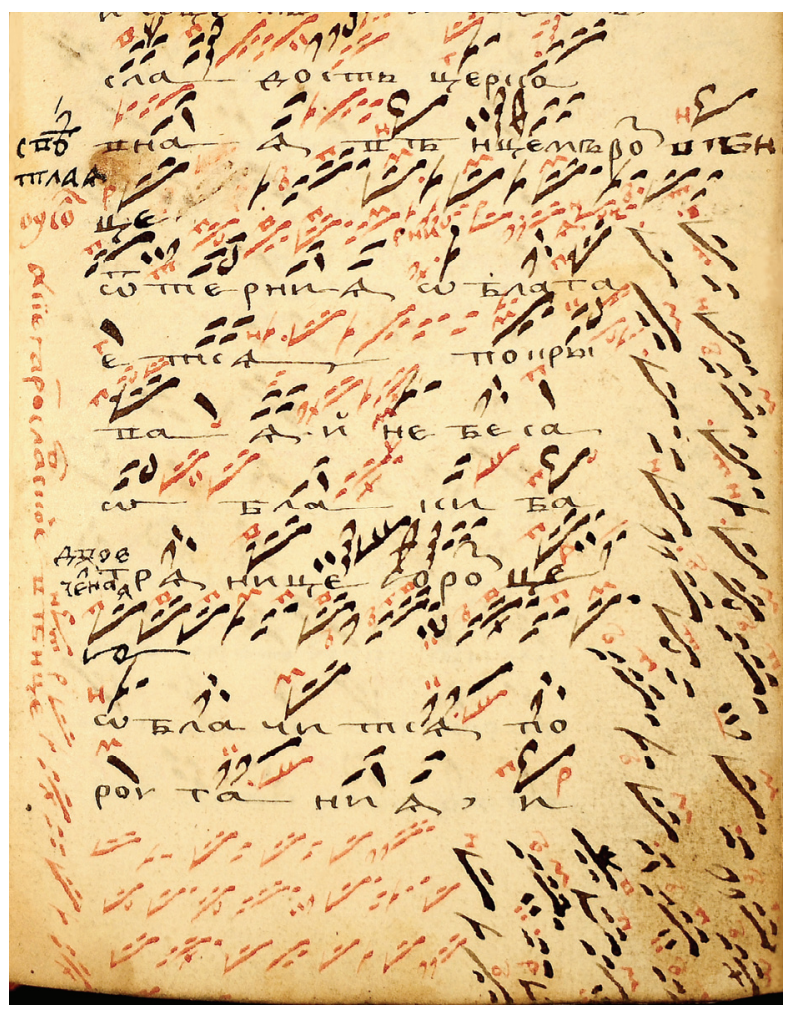

Fig. 3. "Fita" formula in razvod by cinnabar: Usolskiy variant (in the text), "and this is Yaroslavl" (left and bottom margins) [10, fol. 60]

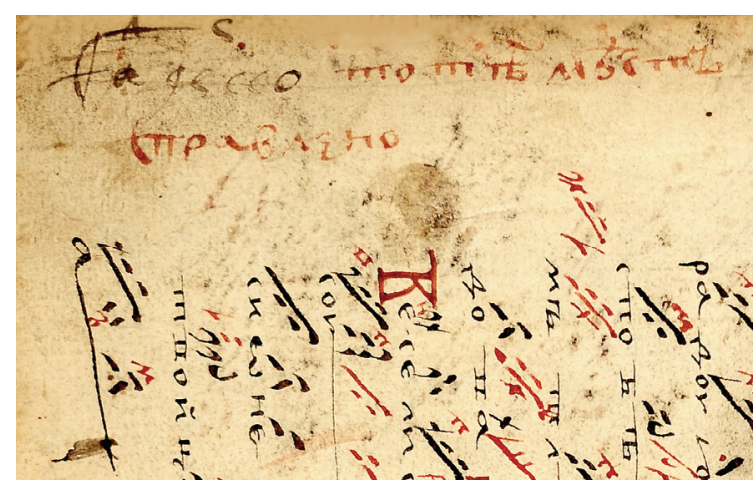

Fig. 5. Notes: «Faddeiko» (black ink) and "I has corrected so far" (cinnabar) [10, fol. 220 back side]

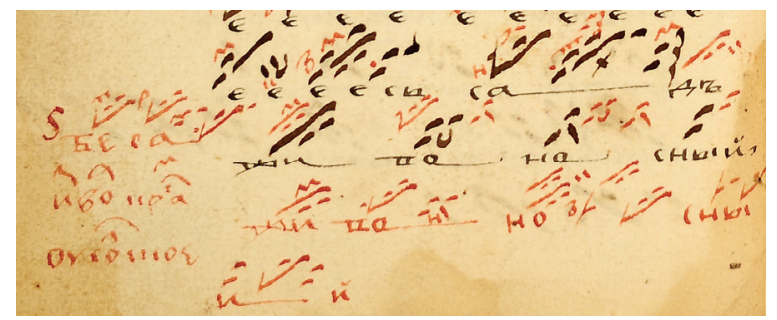

Fig. 2. "Kulizma» formula in razvod in Usolsky version by cinnabar on the margins of manuscript $[10$, fol. 27 back side $]$

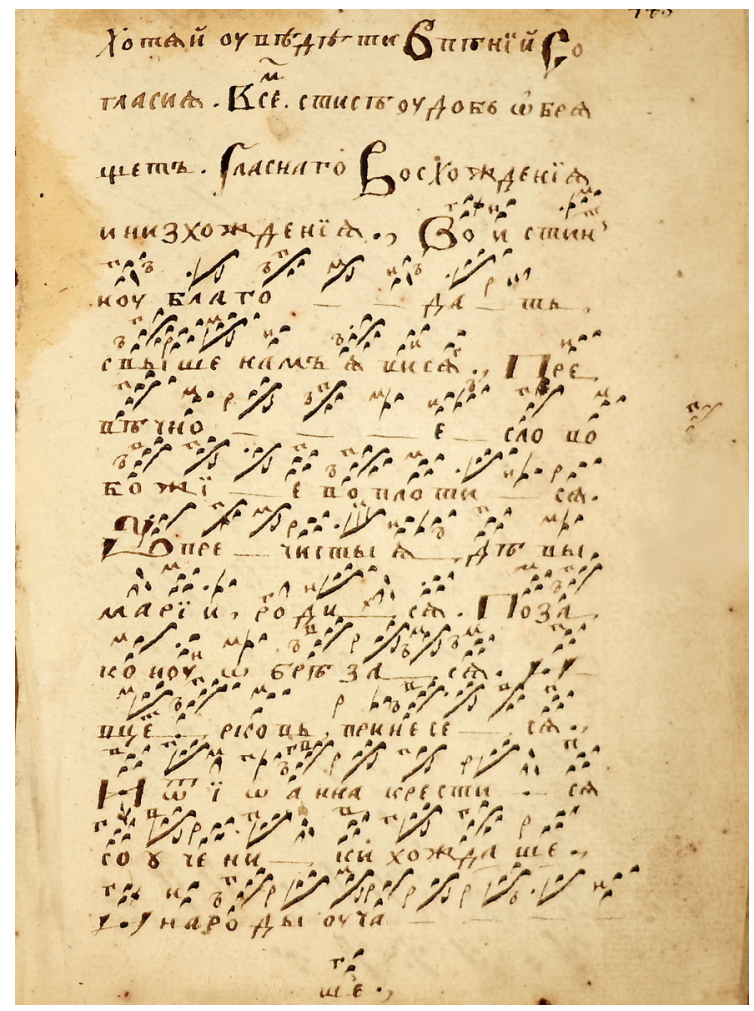

Fig. 4. Exercises to master the steps of the musical scale [10, fol. 445]

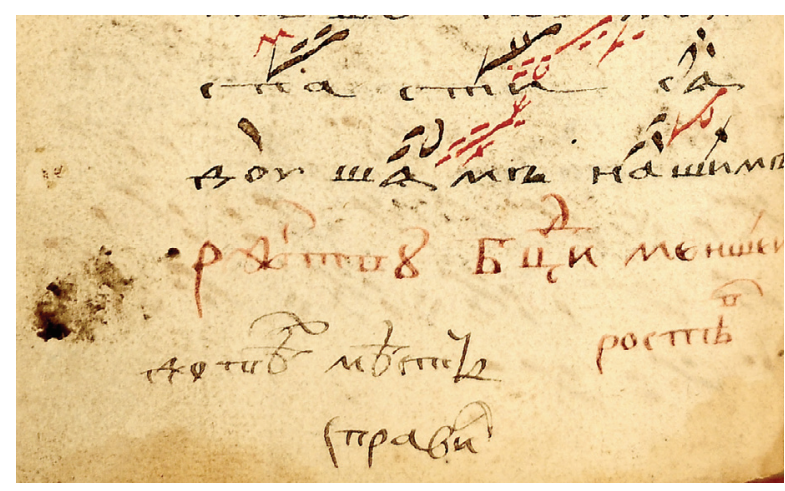

Fig. 6. Note: I has corrected so far [10, fol. 347 back side] 
УДК 783(470.5) + 94(470.5)

DOI: $10.14529 /$ ssh190109

ББК 4611.3 + ТЗ(2Р36)-7 + Щ313(2)

\title{
О НЕКОТОРЫХ ИСТОЧНИКАХ ДЛЯ ИЗУЧЕНИЯ ПРОЦЕССА РЕФОРМИРОВАНИЯ МУЗЫКАЛЬНОГО ИСКУССТВА РОССИИ B XVII B.
}

\author{
Н. П. Парфентьев, \\ Южно-Уральский государственный университет, Челябинск, Российская Федерация
}

\begin{abstract}
В результате деятельности мастеров-дидаскалов (теоретиков), собранных в Москве по указам царя Алексея Михайловича 1652 и 1669 гг., был переработан и отредактирован основной музыкально-гимнографический материал церковно-певческих книг и усовершенствовано крюковое нотное письмо. В ходе музыкальной реформы для более точного обозначения звуковысотности было введено написание при невмах унифицированных буквенных киноварных помет и штриховых призна́ков. Это свидетельствовало о том, что музыкальное мышление мастеров певческого искусства из невменно-формульного трансформировалось к осознанию того, что мелодия состоит из отдельных музыкальных «степе́ней» (ступеней). Все это также сблизило древнерусскую и европейскую музыкальные теории и позволило в будущем осуществить довольно быстрый переход к стилистически новому европеизированному искусству. Автор рассматривает некоторые письменные источники, дающие возможность более обстоятельного изучения практической деятельности мастеров по подготовке и проведению реформы, исследования теоретических принципов их редакторской работы.
\end{abstract}

Ключевые слова: древнерусское иерковно-певческое искусство, музыкальная реформа в России XVII в., рукописные певческие книги, партесное пение.

\section{Литература и источники}

1. Александр Мезенец и прочие. Извещение... желающим учиться пению (1670 г.) / введ., публ., перев. и истор. исслед. - Н. П. Парфентьев ; коммент. и исслед., расшифровка знаменной нотации 3. М. Гусейнова. — Челябинск., 1996.

2. ГАЯО. Кол. рукоп. ОП. 1. № 459 (97).

3. ГИМ. Син. певч. 219.

4. Описание коллекции рукописей Государственного архива Ярославской области XIV-XX вв. / сост. В. В. Лукьянов. - Ярославль, 1957. - С. 88 - 89.

5. Парфентьев, Н. П. Русский распевщик и музыкальный теоретик XVII в. Фаддей Никитин Суботин и его новооткрытые произведения / Н. П. Парфентьев, Н. В. Парфентьева // Памятники культуры. Новые открытия. Ежегодник за 1987 г. - М., 1988. - C. $138-149$.

6. Парфентьев, Н. П. Творческая деятельность московского мастера церковно-певческого искусства XVII в. Луки Ивановича Тверитина / Н. П. Парфентьев // Вестник Южно-Уральского государственного университета. Сер.: Социальногуманитарные науки, 2009. - Вып. 12. - С. 57-62.

7. Парфентьев, Н. П. Хроника творческой деятельности Федора Крестьянина в 1598-1607 гг. / Н. П. Парфентьев, Н. В. Парфентьева // Культура и искусство в памятниках и исследованиях : сб. науч. тр. — Вып. 4. — Челябинск : Изд-во ЮУрГУ, 2006. - С.100-129.

8. Парфентьева, Н. В. Творчество мастеров древнерусского певческого искусства XVI-XVII вв. (на примере произведений выдающихся распевщиков) / Н. В. Парфентьева. — Челябинск : ЧелГУ, 1997.

9. РГБ. Ф. 199. № 146

10. РГБ. Ф. 210. № 12 .

11. РНБ. Кир.-Бел. № 638/895.

12. РНБ. Тит. 4455.

13. Сазонова, Л. И. Придворные поэты XVII в.: стихитворно-музыкальыее композиции / Л. И. Сазонова // Русское музыкальное барокко: тенденции и перспективы исследования : материалы междунар. науч. конф. ; ред.-сост. Н. Ю. Плотникова ; Гос. ин-т искусствознания. - Вып. 1. - М., 2016. - С. $340-347$.

14. Parfentiev, N. P. Preparing and conducting of musical reform in Russia of 1650-1670-ies / N. P. Parfentiev // Bectник Южно-Уральского государственного университета. Серия: Социально-гуманитарные науки, 2017. — Т. 17. — № 3. C. $79-87$.

15. Parfentiev, N. P. The condition of Old Russian musical art by the middle of the XVII century and the prerequisites for its reforming / N. P. Parfentiev // Journal of Siberian Federal University. Humanities \& Social Sciences. — 2017. — V. 10. № 7. - P. 1025-1031.

Поступила в редакцию 03 декабря 2018 z.

ПАРФЕНТЬЕВ Николай Павлович, заведующий кафедрой теологии, культуры и искусства, доктор исторических наук, доктор искусствоведения, профессор, заслуженный деятель науки Российской Федерации, ЮжноУральский государственный университет (Челябинск, Российская Федерация). E-mail: parfentevnp@susu.ru

\section{ОБРАЗЕЦ ЦИТИРОВАНИЯ}

Parfentiev N. P. About some sources for studying of Russian musical art reforming process in $17^{\text {th }}$ century // Вестник ЮУрГУ. Серия «Социально-гуманитарные науки». 2019. - T. 19, № 1. - C. 60-65. DOI: $10.14529 /$ ssh190109

\section{FOR CITATION}

Parfentiev N. P. About some sources for studying of Russian musical art reforming process in $17^{\text {th }}$ century. Bulletin of the South Ural State University. Ser. Social Sciences and the Humanities. 2019, vol. 19, no. 1, pp. 60-65. DOI: $10.14529 / \mathrm{ssh} 190109$ 